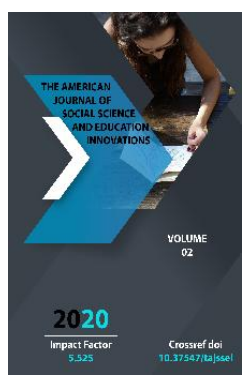

\title{
Central Asian Factor In The Sustainable Development Of Uzbekistan
}

\author{
lymanov Javlon Saidraxmonovich \\ Department Of "Humanities, Andijan Institute Of Agriculture And Agrotechnologies, Andijan, \\ Uzbekistan
}

Journal Website:

http://usajournalshub.c

om/index,php/tajssei

Copyright: Original

content from this work

may be used under the

terms of the creative

commons attributes

4.0 licence.

\section{ABSTRACT}

This article is written on the basis of specific information, examples and evidence about the role of the Republic of Uzbekistan in the Central Asian region, cooperation with neighboring countries, cooperation within international organizations, resolutions for the development of the region, initiatives of the President of Uzbekistan, effective activities under the "Action Strategy", preventive diplomacy with neighboring countries. written on the basis of clear information, examples and evidence of your contribution to security and development.

\section{KEYWORDS}

Central Asia, independent state, eternal friendship, strategic partnership, strategy of action, preventive diplomacy, security, stability, stable environment, development, environmental problem, economic cooperation, development.

\section{INTRODUCTION}

Indeed, today's Uzbekistan is a country that has set a unique and appropriate path of development. In the very short historical period of independence, Uzbekistan has not only achieved great success in the political, legal, economic and spiritual spheres, but also actively participates in enriching the world's socio-political processes with new content 
through a new approach to world politics. Today, we should be proud of the fact that Uzbekistan has a place and prestige in the world community [1]. Central Asia, of course, plays an important role in the sustainable development of Uzbekistan.

\section{MAIN PART}

In the late 1980s, as a result of a rift in the governing system of the former Soviet Union, many of its member states began efforts to achieve the independence they had always dreamed of. As a result, a number of new independent states have appeared on the political map of the world. In particular, in the so-called Central Asian region, there are 5 independent states - Uzbekistan, Kazakhstan, Tajikistan, Turkmenistan and Kyrgyzstan.

The newly independent states should first and foremost establish diplomatic relations with neighboring countries and establish cooperation with them in all areas. In this regard, Uzbekistan has sought to establish diplomatic relations with its close neighbors. Of course, this was due not only to the neighborhood, but also to the common historical and cultural values, traditions, customs and history of the great Turan, Turkestan.

Uzbekistan was one of the first countries to establish diplomatic relations with the Republic of Kazakhstan in 1992. Since then, cooperation between the two countries has been developing on the basis of the agreements between the Republic of Uzbekistan and the Republic of Kazakhstan "On Eternal Friendship" signed in 1998 and the Strategic Partnership between the Republic of Uzbekistan and the Republic of Kazakhstan signed in 2013. Uzbekistan and Kazakhstan have been supporting each other in the international political arena, participating in international organizations such as the UN, SCO and CIS on topical issues of regional significance.

Diplomatic relations were established with the Kyrgyz Republic in 1993. Since then, the centuries-old ties of friendship and good neighborliness between our fraternal peoples have been strengthened, the mutually beneficial Uzbek-Kyrgyz cooperation has significantly expanded, and due to the political will and practical efforts of the parties.

Diplomatic relations with Turkmenistan began in 1993, and cooperation in many areas has continued to this day. In particular, the UzbekTurkmen cooperation has been extensively established since 2016, and now there are Cooperation in almost all spheres.

Although relations with the Republic of Tajikistan began in the early years of independence, as a result of instability in Tajikistan, embassies of the Republic of Tajikistan were officially opened in Tashkent in 1995 and in 2000 in Dushanbe. It should be noted that the First President of Uzbekistan I.A.Karimov described the Uzbek and Tajik peoples as two peoples who speak two languages. Uzbekistan has also made a significant contribution to stabilizing the military-political situation in Tajikistan and finding a positive solution. In September 1992, I.A.Karimov addressed a letter to the UN Secretary-General, drawing the attention of the international community to Tajikistan and calling for a peaceful solution to these problems.

It was established on the initiative of the esteemed head of our state Sh.M.Mirziyoyev as a new stage of development of the Republic of Uzbekistan. Decree No. - PF 4947 
"On the Action Strategy for the five priority areas of development of the Republic of Uzbekistan in 2017-2021" serves as a basis. In particular, paragraph 5.2 of the Action Strategy "Priorities in the field of wellthought-out, mutually beneficial and practical foreign policy" emphasizes the issue of creating an environment of security, stability and good neighborliness around Uzbekistan. [2]

The American political scientist, sociologist and statesman Z. Brzezinski, in his book " The Grand Chessboard ", said that the independence of Uzbekistan is very important for the survival of other countries in Central Asia.[3]

As proof of the views of Z. Brzezinski, the President of the Republic of Uzbekistan Sh.M. Mirziyoyev's initiative and strategic proposals from the highest podiums, and the fact that these proposals are taken into account, further accelerates the policy of Uzbekistan in this area.

The main goal of the foreign policy of the Republic of Uzbekistan is to strengthen the independence, sovereignty, place and role of the state in the international arena, to create an environment of security, stability and good neighborliness. In particular, the support of the new regional policy of Uzbekistan by the Central Asian states shows that the cooperation is carried out systematically. In particular, the initiative of the President of Uzbekistan to organize consultative meetings of Central Asian leaders was proved by the First Consultative Meeting of Central Asian Leaders, which took place in March 2018 in Astana, Kazakhstan.

At the same time, President Shavkat Mirziyoyev noted at the 72nd session of the
UN General Assembly in New York in September 2017 that Uzbekistan attaches great importance to the Central Asian region in its foreign policy, developing cooperation with neighboring countries and ensuring security and regional cooperation. a proposal to introduce a special resolution on strengthening was put forward. In view of these considerations, the special resolution "Strengthening regional and international cooperation to ensure peace, stability and sustainable development in the Central Asian region" adopted by the UN General Assembly for the first time on June 22, 2018 is a historic event for Central Asian states.[4]

It should be noted that the Republic of Uzbekistan is working for the development of not only the country but also the entire region through the development of its own initiatives and effective neighborly relations between the Central Asian states. As noted by President Sh. Mirziyoyev, "Our main goal is to turn Central Asia into a stable, economically developed and highly developed region through joint efforts."[5]

From a socio-philosophical point of view, the Central Asian region is demographically, ethnopsychologically and ethnoculturally similar to the situation in the Balkans, where different cultures have intermingled, new independent states based on multinationalism have emerged.[6]

More than 400 relevant agreements have been signed on regional cooperation. Today, the work in this direction continues.[7]

As we consider a range of issues related to regional security in Central Asia, we must also keep in mind the economic aspects of our cooperation. Because the progress of our countries towards peace, stability, prosperity 
and tranquility can be ensured through multifaceted economic cooperation and economic development.[8]

We know that the sustainable development of Uzbekistan is closely linked with the Central Asian states in a number of areas. It is emphasized that the head of our state Shavkat Mirziyoyev has identified Central Asia as the main priority of our country's foreign policy, a sincere aspiration of our state to establish relations with close neighbors based on the principles of friendship, mutual benefit and good neighborliness.

Uzbekistan, which shares a common border with all Central Asian states, is undoubtedly interested in transforming the region into a region of stability, sustainable development and good neighborliness. Addressing all important issues of the country's development, from the security of our borders to the rational allocation of water resources, is closely linked with our region. Economically developed and secure Central Asia is the main goal for Uzbekistan. Major regional projects in the field of transport, communications and energy cannot be implemented without active cooperation with neighboring countries and ensuring their high level of integration.

Moreover, Central Asia is not only a geographical and geopolitical, but also a unique cultural space with common values. The peoples living in the region are united by common spiritual values and a past, similar national traditions and customs, a mentality formed over the centuries. This partnership is a solid and reliable foundation for regional cooperation.

P. Draganov, head of the UN Regional Center for Preventive Diplomacy for Central Asia, in the participants of the international conference "Central Asia - the main priorities of foreign policy of Uzbekistan" held on August 11, 2017 in Tashkent, he noted that the initiatives of the leadership of Uzbekistan aimed at bringing all Central Asian countries closer together on the path of common development and progress are in line with the main goals and objectives of the United Nations. In this regard, Regional Center for Preventive Diplomacy for Central Asia expressed readiness to implement the proposals of Uzbekistan in this regard.

Another participant of the above international conference, UN Resident Coordinator, UNDP Resident Representative in Uzbekistan $\mathrm{H}$. Fraser, noted that the Action Strategy for 2017-2021 adopted in Uzbekistan and the foreign policy pursued in accordance with it to strengthen relations with neighboring countries it is a guarantee of further prosperity and sustainable development of Asia, and in this regard, the UN fully supports the efforts of Uzbekistan to strengthen regional cooperation.

H. Im, acting OSCE Project Co-ordinator in Tashkent, said that the participation of highranking representatives of Central Asian countries and the diplomatic corps in the conference showed the growing interest of the international community in Tashkent's regional policy to strengthen cooperation in Central Asia.

The conference was attended by leading experts and diplomats from all Central Asian countries - Kazakhstan, Kyrgyzstan, Tajikistan and Turkmenistan. Ambassadors of neighboring countries to Uzbekistan also took part in the discussions. 
Foreign participants noted that the new regional policy of Uzbekistan has radically changed the political environment in Central Asia, creating a solid foundation for effective regional cooperation.

The speeches and comments of the participants showed that the positions of all Central Asian states on topical issues of international cooperation and regional security are close and similar.

The Second Summit of Central Asian Leaders on November 29, 2019 in Tashkent also agreed on a number of issues necessary for effective and sustainable development. In particular, the leaders of the two countries discussed in detail the current state and prospects of cooperation and agreed on the need to further strengthen mutual trust, good neighborliness and partnership between the two countries.

It is known that according to the geostrategic location of Central Asia, it has been at the center of global processes for thousands of years. Because this region has always served as a unique bridge connecting Europe, the Middle East, South and East Asia with its rich cultural and historical heritage. Therefore, even today in Central Asia, the interests of the world's competitive powers intersect.

The solidarity and active efforts of the Central Asian states have opened up new opportunities for multifaceted regional cooperation, and progress has been made in a short period of time.

The proposals made by the President at the second consultative meeting also showed how important the Central Asian states are for the development of Uzbekistan. Including:
First. It is important to mobilize all available forces and capabilities for the implementation of tasks in trade, economic, investment, transport and communications and energy. These are the priorities of ensuring the rapid development and competitiveness of the entire region.

In this regard, he proposed to hold the Central Asian Investment Forum and the first meeting of the Chambers of Commerce and Industry of the countries, to accelerate the establishment of the Regional Council for Transport and Communications.

He proposed to organize an International Tourism Conference to promote joint programs on the principle of "one trip - across the region."

The second. He proposed the establishment of the Inter-Parliamentary Friendship Group of Central Asian countries, as well as the organization of regular multilateral meetings of Deputy Prime Ministers and Foreign Ministers.

Third. Considering that the creation of a platform for cultural and humanitarian exchange under the motto "Central Asia - a single past, a common future" is in the interests of all peoples, the establishment of the Central Asian Award for significant achievements in science, culture and art, as well as university forums and regional offered to organize sports games.

Every year, on the eve of Navruz, the Central Asian Culture Days in each country, in turn, bring all the fraternal peoples closer.

Fourth. Addressing and solving the region's complex water and environmental problems requires a mutually coordinated approach. 
In order to attract innovative technologies, implement the principles of the "green economy", eliminate the negative effects of desertification and take other comprehensive measures, it is important to effectively use the resources of the Trust Fund for the UNsponsored Aral Sea region. it is necessary to continue to look for an optimal solution for all. Fifth. The most important priority is to ensure regional stability and security.

Establishment of working mechanisms for operational cooperation of law enforcement agencies and special services of the countries to counter modern threats and challenges on a large scale.

Afghanistan is an integral part of the Central Asian region. It is in the common interest of all to help this country take a firm step on the path of peace and development.

It is necessary to follow the basic principles of political solution of the problem. First and foremost, it is a renunciation of violence, a ceasefire, a willingness to communicate and compromise.

In addition, it is important to implement important infrastructure and social projects in Afghanistan, as well as to develop coordinated approaches aimed at the active involvement of this country in regional trade and economic relations.[9]

We all know that the Central Asian states have been under many invasions to this day. But these invaders did not completely and forever lose the ancient values of Central Asian civilization, they were renewed each time, denying their old aspects and gradually adjusting their values.
Social progress, the life of a society, is not a series of historical changes that go smoothly without jumps and setbacks, various contradictions and contradictions. Human history moves from the past to the future through various contradictions and contradictions. At the same time, the values of certain civilizations develop in the same way, more and more clearly reflecting the more perfect aspects and diversity of universal, national-ethnic and other values. In our opinion, the Central Asian civilization has a similar feature. It also takes its values through a series of times, renews, improves, discovers colorful characters, demonstrates its diversity. This system of common values inherent in civilization also reflects the realities of each changing period, reveals new aspects and aspects in the overall picture, but each time preserves the spirit of ancestors, universal ideals, love of ethnic space, human traditions and becomes an independent system based on them. The same can be seen in the new system of values emerging in independent Uzbekistan.[10]

The threat of a "cold war" between the two regimes that ruled during the twentieth century has disappeared. It is now important to move from a policy of mutual hostility and conflict in the past to a policy of cooperation.

Given the persistence of ethnic and interethnic conflicts on the planet, as well as the threat of thermonuclear war and international terrorism, and the intensification of various forms of political and religious extremism, it is necessary for states and peoples to work together to combat them. It is also important to encourage the process of uniting the efforts and economic potential of most countries in the world, especially the newly independent states, to become equal members of the strongest, largest international banks and influential 
international organizations. This is especially important for the Central Asian republics. [11]

\section{CONCLUSION}

From the above, it can be concluded that from a socio-philosophical point of view, Central Asia is literally a body - brothers and sisters who show that they should support each other and be a shield for each other in every age and time. The current geographical, economic, socio-political situation in Central Asia requires the creation of a single concept of a stable environment, combining the efforts and capabilities of philosophers in the region.

\section{REFERENCES}

1. Karmiov I.A. From the path of creativity. Tashkent. Uzbekistan. 1996.132 p. [1]

2. Karimov I.A. We must fight for security and peace. Tashkent. Uzbekistan. 2002. 367 p. [8]

3. Decree of the President of the Republic of Uzbekistan Sh.M.Mirziyoyev dated February 7, 2017 No PF-4947 "On the strategy of further development of the Republic of Uzbekistan". Newspaper "Xalq so'zi" February 8, 2017. [2]

4. Speech by the President of the Republic of Uzbekistan Sh.M.Mirziyoyev at the Second Summit of Central Asian Leaders on November 29, 2019 in Tashkent. https://uza.uz/oz/politics/-zbekistonrespublikasi-prezidenti-shavkatmirziyeevning-mar-30-11-2019 [9]

5. Speech by President of the Republic of Uzbekistan Shavkat Mirziyoyev at the 72nd session of the United Nations General Assembly on September 19, 2017. http://uza.uz/oz/politics/zbekistonprezidenti-shavkat-mirziyeev-bmt-boshassambleyasi-20-09-2017 [4]
6. Speech by President of the Republic of Uzbekistan Shavkat Mirziyoyev at the International Conference "Central Asia: Common History and Common Future, Cooperation for Sustainable Development and Progress" held in Samarkand on November 10-11, 2017. http://uza.uz/oz/politics/zbekistonrespublikasi-prezidenti-shavkatmirziyeevning-sama-10-11-2017 [5]

7. Zbigniew Brzezinski. The Grand Chessboard (chapters from the book). https://ziyouz.uz/ilm-va-fan/tarix/zbignevbjezinskiy-buyuk-shaxmat-tahtasi-kitobdanboblar/ [3]

8. Interfaith harmony is a factor of social stability. Monograph / I. Saifnazarov, A. Obidov. - Tashkent: Innovative Development Publishing House, 2019. (142 p.) $18-19$ p. [6]

9. Tashkent remains the political capital of Asia. Newspaper “Xalq so'zi” June 252016. [7]

10. Nazarov Q. Philosophy of Values (Axiology). Tashkent. Publishing House of the National Society of Philosophers. 2004. (p. 85) 68 p. [10]

11. Karimov I., Rustamova M. History and Theory of Philosophy Methodical manual for students and teachers of higher education institutions. Nizami TDPU Publishing House, 2006. (110 pages) 108 b. [11] 